\title{
Application of Big Data Model in Financial Taxation Management
}

\author{
Li Lin (iD) \\ Accounting School/Finance and Accounting Research Center, Fujian Jiangxia University, Fuzhou 350108, China
}

Correspondence should be addressed to Li Lin; 2008019@fjjxu.edu.cn

Received 13 October 2021; Revised 5 November 2021; Accepted 10 November 2021; Published 30 November 2021

Academic Editor: Sikandar Ali

Copyright ( $) 2021 \mathrm{Li}$ Lin. This is an open access article distributed under the Creative Commons Attribution License, which permits unrestricted use, distribution, and reproduction in any medium, provided the original work is properly cited.

We have entered an era of information technology. Many financial and taxation management tasks have been applied to big data technology. Through big data technology, we can efficiently collect data and Internet information, realize efficient management of information, and establish a complete set of tax database. The research results of the article show the following. (1) We analyze the application status of big data technology and put forward the problems and solutions in data processing in our country. (2) Most financial managers of small and medium-sized enterprises are rather vague about the definition of taxation. Training in this area should be strengthened. Taking the industrial chain of Chinese enterprises as the survey object, the concept of taxation compliance and influencing factors have been elaborated, and a taxation respect model has been established. The investigation method can be analyzed through the model. (3) We established the coefficient of variation model with Pilka coefficient and found that the main business income has the highest correlation with the value-added tax payable and has the strongest linear relationship; the correlation between return on assets and value-added tax payable is the weakest, and there is a weak relationship. There is a strong negative correlation between sales profit margin and VAT payable (4) Taking a pharmaceutical company in our country as the subject of investigation, the company's financial operating conditions have been studied for the past ten years, and it is concluded that the company's main business income is increasing year by year, and the corresponding tax revenue is also increasing, and the tax growth rate is relatively unstable. Among them, the financial risk coefficient of corporate income tax is the largest.

\section{Introduction}

At present, our country has entered an important period of comprehensive deepening of economic development. A large amount of taxes and fees will be generated when conducting money transactions. Traditional financial management methods can no longer meet the needs of today's social development. We have entered the era of big data. As the fastest-developing technology, big data has also brought great convenience to our daily lives. Literature [1] mainly discusses the application research of fiscal and taxation big data in corporate taxation risk management. Big data technology has been widely used in various industries, and deploying big data technology as soon as possible is also the goal of many computer workers. Literature [2] shows that the development pattern of financial data application with full system coverage, business cooperation, and open sharing should be gradually formed. Literature [3] proposed the application of artificial intelligence and big data in the field of finance and taxation. Literature [4] investigates the consequences of major internal control deficiencies (ICW) related to taxation. Literature [5] highlights its advantageous role in data processing in the financial industry and avoids financial risks. The sharing of information resources between networks is necessary to realize the exchange of information between the taxation department and the government through an effective platform area. Literature [6] theoretically designed and implemented the taxation electronic network system based on the perspective of the Internet and big data. Literature [7] studies whether banks owned by bank holding companies coordinate their security gains and losses to manage their tax, income, and capital management goals. How to attract foreign direct investment is also an issue that we must consider when carrying out business reforms. Open trade will lead to capital flows. Therefore, a country must have appropriate laws and regulations to regulate transfer pricing. Literature [8] shows that big data and artificial intelligence will bring additional 
tools for developing countries to obtain income in the fiscal environment triggered by the new crown. Literature [9] investigated whether the adoption of International Financial Reporting Standards (IFRS) in Greece will affect the incentives of tax incentives for financial earnings management. Literature [10] solves the empirical problem that capital cannot usually flow from a rich or slow-growing country to a poor or fast-growing country. For a long time in the past, the government has taken many measures to exchange a large amount of tax information with other departments, actively encouraging the strengthening of information sharing, but the privacy and personal information of certain taxpayers cannot be further protected. Literature [11] mainly states that the government should balance the interests of taxpayers and tax authorities. Literature [12] examined the correlation between audit fees and credit ratings assessed by credit rating agencies. Literature [13] defines a new logical thread "big data technology-artificial intelligence industryeconomic law." The use of algorithms in literature [14] has reference value for microdata, complex data, and data analysis. Financial management is to systematically sort and research the massive data collected. Big data technology can not only help us collect financial data efficiently but also systematically sort these data for us to consult. Literature [15] investigates the impact of government intervention through unemployment relief on macroeconomic dynamics in an agency-based decentralized matching framework.

With the rapid development of information technology, tax collection and management has entered the era of big data. Due to the wide application of data informatization, tax work has not only ushered in unprecedented development opportunities but also encountered various challenges. If the response is not effective, it will bring adverse effects to the tax work. In the era of rapid development of information technology, the mining and utilization of big data is of great significance to tax administration. The application and development of big data technology will meet the needs of tax collection and management after tax authorities merge. Big data will be introduced into tax analysis, and the strength of tax analysis will be continuously enhanced through multidimensional analysis and comparison to provide data support for tax collection and management.

\section{Analysis of the Status Quo of Big Data Applications}

According to the research results, the financial managers of enterprises have a big deviation in their understanding of taxation. They believe that taxation is the main responsibility of the State Administration of Taxation, and they only need to pay taxes and fees on time in accordance with the requirements of the law. The training of tax law knowledge has not received enough attention in our country's small and medium-sized enterprises, which will cause the level of financial management personnel of the enterprise to be unable to be further improved. The demand of tax offices and other related institutions in our country is constantly increasing under the promotion of economic development. Under normal circumstances, short-answer tax planning is mainly carried out by enterprises, while more complicated tax planning must be undertaken by professional institutions. Although professional institutions can promote the implementation of national preferential policies to a certain extent, they will also be affected by many factors, causing problems such as agency violations. Enterprises should pay attention to the improvement of the professional quality of financial staff. Tax staff must fully understand the risk control of tax planning. They must not only possess professional knowledge but also proficiently apply various skills in actual work. Enterprises should strengthen the training of tax management knowledge and improve the management ability, communication ability, and decision-making ability of employees. In addition, corporate managers must combine the actual situation with finance as the core to continuously improve the existing tax management system. In this process, managers must pay attention to the effective application of financial management methods and improve the efficiency of corporate tax management.

\subsection{The Impact of Big Data on Corporate Tax Management.} In the context of rapid economic development, many companies are also experiencing good development, and some tax management concepts have also been accepted by many companies. However, most companies do not pay enough attention to tax management in the financial department, and companies lack professional talents. Paying attention to financial and taxation management will not only affect the normal operating conditions of the enterprise but also cause some adverse effects on the long-term development of the enterprise. It is necessary for the company's management to have a strong financial risk awareness for the development of the company. To a certain extent, the company can avoid a lot of financial crises. Of course, they must also have strong professional qualities and must be able to use intelligence. The system also organizes the collected data.

2.2. Recommendations for Tax Management in the Context of Big Data. The most basic function of an intelligent data analysis platform should be to collect a large amount of tax data. After collecting relevant data, the platform should compare the data and set a standard value to predict tax crises. The data system will give strong reminders to those that exceed the standard value, so that some tax crisis problems can be avoided. Tax management has high requirements for managers. They must not only understand some legal knowledge related to taxation but also have strong professional capabilities. They will use many intelligent applications, so companies should pay more attention to professional talents and cultivate and train more to improve the skills of employees. Enterprise tax management is the top priority of enterprise management. It is not only related to the future development of the enterprise but also affects the profitability of the enterprise. Therefore, the financial and tax management of the enterprise should be given top priority. Enterprises should set up relevant rules and regulations, with a clear division of labor, to provide a 
good guarantee for the financial management of the enterprise. The tax management of an enterprise is a very long process. Managers should be clear about the process of each step, do the preliminary tax accounting work, calculate the corresponding amount, and then report it and do a good job of leveling. Enterprises should pay taxes and fees on time in accordance with legal requirements, and staff should communicate with tax authorities in a timely manner to prevent problems.

\section{Concept Definition and Influencing Factor Analysis of Tax Compliance}

3.1. The Basic Theory of Tax Compliance. The basic theory for studying tax obedience is the expected utility maximization model (A-S model) [16]. Construct the objective function [17]:

$$
E(U)=(1-p) U(\omega-\gamma X)+\rho U[\omega-\gamma X-\eta(\omega-X)] .
$$

Basic Assumptions of the A-S Model. As a taxpayer, the individual is a "rational economic man," who aims at maximizing expected utility and is a risk avoider without the concept of moral right and wrong. His behavior is in line with VNM utility function, and the utility function takes personal disposable income as the only parameter. In the above objective function, $X$ is the total income newly obtained by the taxpayer and $\omega$ is the taxable income declared to the competent tax authorities. The applicable proportional tax rate $\gamma$ is the amount of change that the taxpayer knows, but the tax department cannot grasp, $X \geq 0 ; \rho$ is the inspection rate or the probability of tax evasion being discovered, assuming that it is a fixed rate, so it is a constant greater than 0 . If tax evasion is found, the penalty rate per unit of undeclared income is $\eta, \eta>0 . E(U)$ Represents the expected utility of the taxpayer, which can be obtained from formula (1): the taxpayer seeks $E(U)$ to be the largest, which can be accomplished by changing the actual declared income $X$. Conditions of non-compliance by taxpayers for financial taxation:

$$
\begin{aligned}
& \frac{\mathrm{d} E(U)}{\mathrm{d} x}<0, \\
& \frac{\mathrm{d} E(U)}{\mathrm{d} x}=-\gamma(1-p) U^{\prime}(\omega-\gamma X)-(\gamma-\eta) \rho U^{\prime}[\omega-\gamma X-\eta(\omega-X)],
\end{aligned}
$$

which is

$$
-\gamma(1-\rho)-(\gamma-\eta) \rho<0
$$

If taxpayers adopt tax non-compliance behaviors,

$$
\rho \eta<\gamma
$$

Government departments should increase the probability of seizure and punishment [18].

\subsection{Game Analysis of Tax Compliance}

3.2.1. Establishment of Game Model. The actual taxable income of an enterprise in tax declaration period $T$ is $X$, the actual tax amount declared is $x(0<x<X)$, the proportional tax rate is $\gamma(0<\gamma<1)$, and the total amount of tax paid by the enterprise based on the actual tax payment is $X \gamma$ [19]; if the enterprise does not follow the actual situation, the tax will be paid. The amount is $x \gamma$, and the amount of tax evasion is $(X-x) \gamma[20]$. If the probability of an enterprise misreporting its tax status is $\rho_{1}$, then the actual tax rate declared by the company is $1-\rho_{1}$; the probability of checking the tax status of the State Administration of Taxation is $\rho_{2}$, the tax cost received by the company is $C_{1}\left(C_{1}>0\right)$, and the tax inspection cost of the tax bureau is $C_{2}\left(C_{2}>0\right)$. The enterprise shall pay a fine of $n(X-x) \gamma$ and pay $(X-x) \gamma$ of taxes and fees. You can build a matrix, as shown in Table 1.
3.2.2. Analysis of Behavioral Game Equilibrium. From Table 1, we can get

$$
X \gamma>X \gamma-C_{2}
$$

Likewise:

$$
C_{2}>(1+n)(X-x) \gamma \text {. }
$$

The tax bureau will choose not to conduct tax audits if

$$
X-x \gamma>X(1-\gamma) \text {. }
$$

Obtainable benefits:

$$
C_{2}<(1+n)(X-x) \gamma
$$

The proceeds from tax inspections are

$$
\left[X \gamma-C_{2}+n(X-x) \gamma\right]^{*} \rho_{1}+\left(X \gamma-C_{2}\right) *\left(1-\rho_{1}\right) \text {. }
$$

The benefits of not choosing tax audits are

$$
x \gamma * \rho_{1}+X \gamma *\left(1-\rho_{1}\right) \text {. }
$$

Let (9) be equal to (10), and we get

$$
\rho_{1}<\frac{C_{2}}{(1+n)(X-x) \gamma} .
$$

The benefits of non-compliance with taxes during the operation period of the enterprise are 
TABLE 1: Game income matrix of taxation departments and enterprises.

\begin{tabular}{lcc}
\hline Tax department & Tax compliance & Tax non-compliance \\
\hline \multirow{2}{*}{ Tax inspection } & $X-X \gamma-C_{1}$ & $X-x \gamma-C_{1}-(1+n)(X-x) \gamma$ \\
& $X \gamma-C_{2}$ & $X \gamma-C_{2}+n(X-x) \gamma$ \\
Tax non-audit & $X(1-\gamma)$ & $X-x \gamma$ \\
& $X \gamma$ & $x \gamma$ \\
\hline
\end{tabular}

$$
\left[X-x \gamma-C_{1}-(1+n)(X-x) \gamma\right] * \rho_{2}+(X-x \gamma) *\left(1-\rho_{2}\right)
$$

The benefits of tax compliance are

$$
\left(X-X \gamma-C_{1}\right) * \rho_{2}+X(1-\gamma) *\left(1-\rho_{2}\right) .
$$

Set (12) equal to (13), and we get

$$
\rho_{2}^{*}=\frac{1}{1+n}
$$

The benefits of corporate tax non-compliance are

$$
U=\left[X-x \gamma-C_{1}-(1+n)(X-x) \gamma\right] * \rho_{2}+(X-x \gamma) *\left(1-\rho_{2}\right) \text {. }
$$

Differentiate

$$
\frac{\mathrm{d} U}{\mathrm{~d} \rho_{2}}=-(1+n)(X-x) \gamma-C_{1} .
$$

Because $n>0, X>x, C_{1}>0$, so $\mathrm{d} U / \mathrm{d} \rho_{2}<0$.

\subsection{Demonstration of Tax Compliance Problem}

3.3.1. The Establishment of a Comprehensive Coefficient of Variation Model. Use Picard's correlation coefficient [21] to analyze the correlation of indicators:

$$
R=\frac{\sum_{i=1}^{n}\left(X_{i}-\bar{X}\right)\left(Y_{i}-\bar{Y}\right)}{\sqrt{\sum_{i=1}^{n}\left(X_{i}-\bar{X}\right)^{2}} \sqrt{\sum_{i=1}^{n}\left(Y_{i}-\bar{Y}\right)^{2}}} .
$$

Average index:

$$
\bar{X}=\frac{1}{n} \sum_{i=1}^{n} X_{i}
$$

Indicator standard deviation:

$$
\sigma=\sqrt{\frac{\sum_{i=1}^{n}\left(X_{i}-\bar{X}\right)^{2}}{n-1}} .
$$

Industry comprehensive coefficient of variation:

$$
C V=\sum_{i=1}^{n} \frac{\sigma_{i}}{X_{i}}
$$

The comprehensive coefficient of variation of the specific evaluation object [22]:

$$
C V=\sum_{i=1}^{n} \frac{X_{i}}{\bar{X}_{i}}
$$

Upper limit of the warning value of the comprehensive coefficient of variation:

$$
C V=\sum_{i=1}^{n} \frac{M}{\bar{X}_{i}}
$$

Lower limit of warning value of comprehensive coefficient of variation:

$$
C V=\sum_{i=1}^{n} \frac{m}{\bar{X}_{i}}
$$

When the correlation coefficient $>0.6$, the upper limit of the warning value is

$$
M=\bar{X}+0.6 * \bar{X}
$$

Lower limit of warning value:

$$
m=\bar{X}+0.6 * \bar{X} \text {. }
$$

When the correlation coefficient is less than 0.6 , the upper limit of the warning value is

$$
M=\bar{X}+\sigma
$$

Lower limit of warning value:

$$
m=\bar{X}+\sigma \text {. }
$$

3.3.2. Application of Comprehensive Coefficient of Variation Model. A larger value of $|R|$ indicates a higher degree of correlation, and $|R|=0$ indicates no correlation [24]. Financial indicators are shown in Table 2.

According to Table 2, we can conclude that the main business income has the highest correlation with the valueadded tax payable and has the strongest linear relationship [25]; the return on assets has the weakest correlation with the value-added tax payable and has a weak relationship; sales profit rate has a strong negative correlation with the VAT payable. The main business cost has the highest correlation with the corporate income tax payable and has the strongest linear relationship. The return on assets has the weakest corporate income tax payable and has a weak relationship. The sales profit rate has a strong negative correlation with the corporate income tax payable; operating profit, total profit, inventory turnover rate, and asset turnover rate have a strong positive correlation with value-added tax payable and corporate income tax payable.

\section{Experimental Simulation}

4.1. Scale Analysis. Big data technology can be applied to all walks of life, and each industry has its own unique characteristics. We take the pharmaceutical industry as the standard, analyze the business status of the industry, and 
TABLE 2: Correlation coefficients of financial indicators.

\begin{tabular}{|c|c|c|c|c|c|c|c|c|c|c|}
\hline Year & Income & Cost & $\begin{array}{c}\text { Operating } \\
\text { profit }\end{array}$ & $\begin{array}{l}\text { Total } \\
\text { sales }\end{array}$ & $\begin{array}{c}\text { Sales profit } \\
(\%)\end{array}$ & $\begin{array}{l}\text { Inventory turnover } \\
\text { rate }\end{array}$ & Assets & $\begin{array}{c}\text { Asset turnover rate } \\
(\%)\end{array}$ & $\begin{array}{l}\text { VAT } \\
\text { Y1 }\end{array}$ & $\begin{array}{c}\text { Tax payable } \\
\text { Y2 }\end{array}$ \\
\hline 2008 & 7402.9 & 5061.9 & 844.62 & 792.9 & 10.71 & 0.917 & 0.121 & 100.04 & 398.24 & 117.99 \\
\hline 2009 & 9087 & 6262.7 & 1002.77 & 993.9 & 10.94 & 0.998 & 0.126 & 105.52 & 453.48 & 134.16 \\
\hline 2010 & 11417.1 & 7902.4 & 1349.98 & 1331.0 & 11.66 & 1.039 & 0.139 & 111.62 & 547.12 & 169.98 \\
\hline 2011 & 14484 & 10277 & 1634.91 & 1606.0 & 11.09 & 1.055 & 0.143 & 119.03 & 670.28 & 213.63 \\
\hline 2012 & 17337.6 & 12161 & 1841.51 & 1865.8 & 10.76 & 1.107 & 0.140 & 119.62 & 822.54 & 254.18 \\
\hline 2013 & 20484.2 & 14462 & 2091.58 & 2132.7 & 10.41 & 1.127 & 0.136 & 119.73 & 990.29 & 297.6 \\
\hline 2014 & 23350.3 & 16576 & 2328.02 & 2382.4 & 10.20 & 1.129 & 0.130 & 116.20 & 1109.7 & 247.16 \\
\hline$R_{Y_{2}}$ & 0.9979 & 0.997 & 0.9861 & 0.9890 & -0.66 & 0.921 & 0.347 & 0.7797 & 1 & \\
\hline$R_{Y_{2}}$ & 0.9991 & 0.999 & 0.9915 & 0.9931 & -0.63 & 0.927 & 0.369 & 0.7931 & & 1 \\
\hline
\end{tabular}

TABLE 3: Total business scale.

\begin{tabular}{ccccccc}
\hline Years & Income & $\begin{array}{c}\text { Income growth rate } \\
(\%)\end{array}$ & $\begin{array}{c}\text { Income of wholesale enterprises } \\
(\%)\end{array}$ & $\begin{array}{c}\text { Total } \\
\text { profit }\end{array}$ & $\begin{array}{c}\text { Total profit growth rate } \\
(\%)\end{array}$ & $\begin{array}{c}\text { Wholesale enterprises } \\
(\%)\end{array}$ \\
\hline 2008 & $7,402.33$ & 24.05 & 25.09 & 792.90 & 36.41 & 12.55 \\
2009 & $9,087.00$ & 22.76 & 28.61 & 993.96 & 25.36 & 13.02 \\
2010 & $11,417.30$ & 25.64 & 20.65 & 1331.09 & 33.92 & 53.58 \\
2011 & $14,484.38$ & 26.86 & 10.39 & 1606.02 & 20.65 & 15.73 \\
2012 & $17,337.67$ & 19.70 & 11.77 & 1865.89 & 16.18 & 0.84 \\
2013 & $20,592.93$ & 18.78 & 6.58 & 2071.67 & 11.03 & -0.45 \\
2014 & $23,350.33$ & 13.39 & 0.25 & 2382.47 & 15.00 & -2.89 \\
2015 & $25,729.53$ & 10.19 & 4.43 & 2717.35 & 14.06 & 8.66 \\
2016 & $28,206.11$ & 9.63 & -2.23 & 3114.99 & 14.63 & 6.74 \\
2017 & $27,116.57$ & -3.86 & & 3324.81 & & 4.16 \\
\hline
\end{tabular}

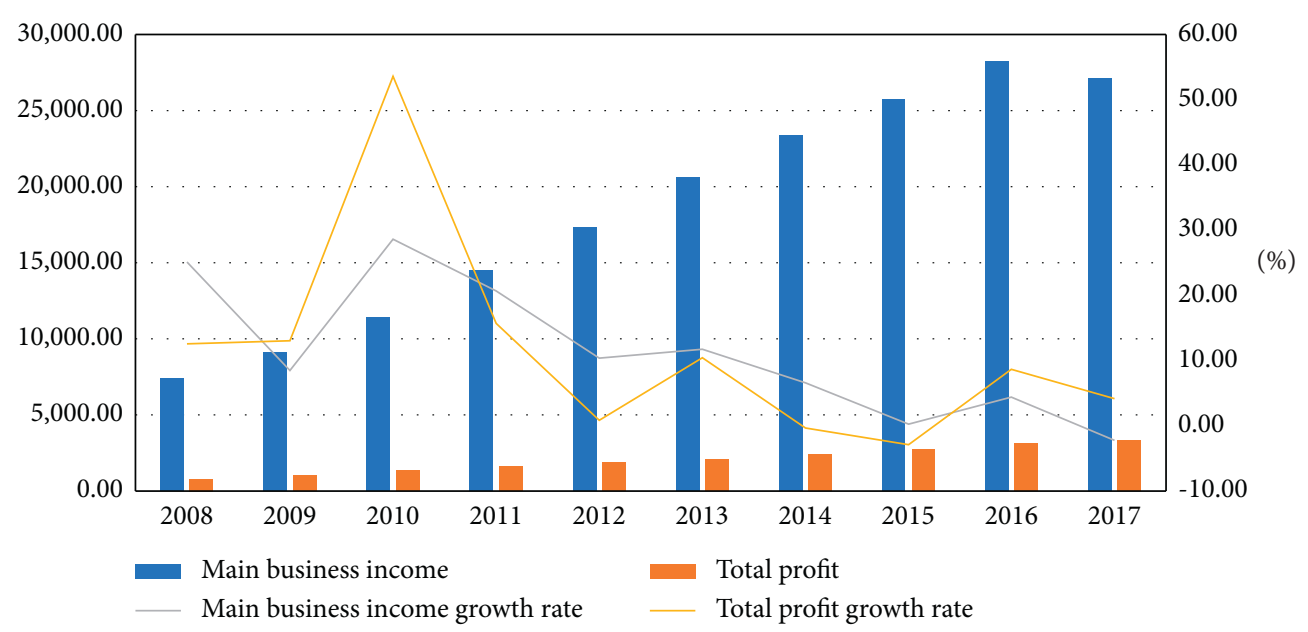

FIGURE 1: Trend chart of total operating profit.

then analyze the tax management issues of the pharmaceutical industry through big data technology. We have investigated the business scale of our country's pharmaceutical manufacturing industry in the past ten years. The specific questionnaire is shown in Table 3, and the development trend chart is shown in Figure 1.

We can find from Figure 1 that from 2008 to 2017, the main operating income showed a growth trend, but the increase was slowly decreasing, and the main operating income reached its peak in 2016. The total profit also showed an increasing trend from 2008 to 2017, but the growth rate continued to decrease as shown in Table 4.

We can find from Figure 2 that from 2008 to 2017, the operating income of equipment business owners showed an upward trend, reaching the maximum in 2017. The tax analysis is shown in Table 5, and the trend chart is shown in Figure 3. 
TABLE 4: Equipment wholesale revenue and operating profit scale.

\begin{tabular}{|c|c|c|c|c|c|c|}
\hline Years & Income & $\begin{array}{l}\text { Income growth rate } \\
(\%)\end{array}$ & $\begin{array}{c}\text { Income of wholesale } \\
\text { enterprises }(\%)\end{array}$ & $\begin{array}{c}\text { Profit from principal } \\
\text { operations }\end{array}$ & $\begin{array}{l}\text { Profit growth rate } \\
(\%)\end{array}$ & $\begin{array}{c}\text { Wholesale } \\
\text { enterprises (\%) }\end{array}$ \\
\hline 2008 & $5,273.04$ & 39.68 & 62.65 & 507.26 & 97.69 & 76.36 \\
\hline 2009 & $6,129.11$ & 13.97 & -7.34 & 502.98 & -0.84 & -5.77 \\
\hline 2010 & $7,202.80$ & 17.52 & 39.11 & 627.40 & 24.74 & 18.51 \\
\hline 2011 & $9,334.08$ & 29.59 & 31.01 & 854.26 & 36.16 & 24.58 \\
\hline 2012 & $10,772.64$ & 15.41 & 12.41 & 1071.56 & 25.44 & 6.48 \\
\hline 2013 & $13,498.71$ & 25.31 & 21.15 & 1358.38 & 26.77 & 27.90 \\
\hline 2014 & $15,927.05$ & 17.99 & 7.22 & 1633.58 & 20.26 & -0.49 \\
\hline 2015 & $18,146.16$ & 13.93 & -9.36 & 1939.66 & 18.74 & -4.67 \\
\hline 2016 & $20,595.71$ & 13.50 & 6.61 & 2283.9 & 17.75 & 10.20 \\
\hline 2017 & $23,791.33$ & 15.52 & 16.96 & 2884.61 & 26.30 & 6.46 \\
\hline
\end{tabular}

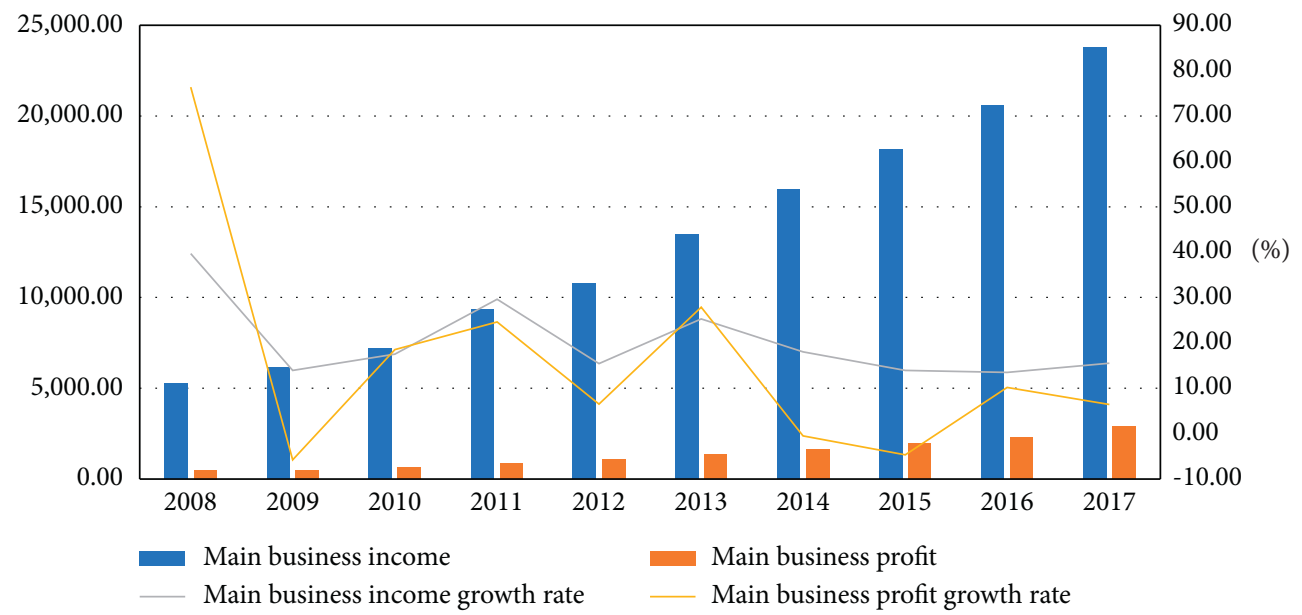

FIGURE 2: Operating profit trend chart.

TABLE 5: Tax analysis form of main business.

\begin{tabular}{|c|c|c|c|c|c|c|}
\hline Years & Income & Income (wholesale) & Total profit & Main profit & VAT (\%) & Income tax (\%) \\
\hline 2008 & $7,402.33$ & $5,273.04$ & 792.90 & 507.26 & 97.69 & 76.36 \\
\hline 2009 & $9,087.00$ & $6,129.11$ & 993.96 & 502.98 & -0.84 & -5.77 \\
\hline 2010 & $11,417.30$ & $7,202.80$ & 1331.09 & 627.40 & 24.74 & 18.51 \\
\hline 2011 & $14,484.38$ & $9,334.08$ & 1606.02 & 854.26 & 36.16 & 24.58 \\
\hline 2012 & $17,337.67$ & $10,772.64$ & 1865.89 & 1071.56 & 25.44 & 6.48 \\
\hline 2013 & $20,592.93$ & $13,498.71$ & 2071.67 & 1358.38 & 26.77 & 27.90 \\
\hline 2014 & $23,350.33$ & $15,927.05$ & 2382.47 & 1633.58 & 20.26 & -0.49 \\
\hline 2015 & $25,729.53$ & $18,146.16$ & 2717.35 & 1939.66 & 18.74 & -4.67 \\
\hline 2016 & $28,206.11$ & $20,595.71$ & 3114.99 & 2283.9 & 17.75 & 10.20 \\
\hline 2017 & $27,116.57$ & $23,791.33$ & 3324.81 & 2884.61 & 26.30 & 6.46 \\
\hline
\end{tabular}

\subsection{Analysis of Taxation Scale}

4.2.1. Corporate Tax Composition. The tax types and percentages of enterprises are shown in Figure 4.

4.2.2. Analysis of Taxation. The article collects the taxation status of corporate taxation from 2015 to 2017 . The specific conditions are shown in Table 6.

We can draw from Table 7 that the various tax burden index rates of enterprises have shown an increasing trend, and the index values have been higher than the industry average. The tax status of enterprises is shown in Table 8.
We can see from Figure 5 that the peculiar tax amount will increase with the growth of corporate profits. Among them, corporate income tax occupies the largest amount of tax, so in the financial risk control of enterprises, the focus should be placed on corporate income tax, which can prevent the financial crisis of the enterprise to a large extent.

4.2.3. Scale Analysis. From the data in Table 9, we can conclude that from 2016 to 2016, although the ratio of valueadded tax to taxation was declining, the overall ratio still exceeded $60 \%$. 


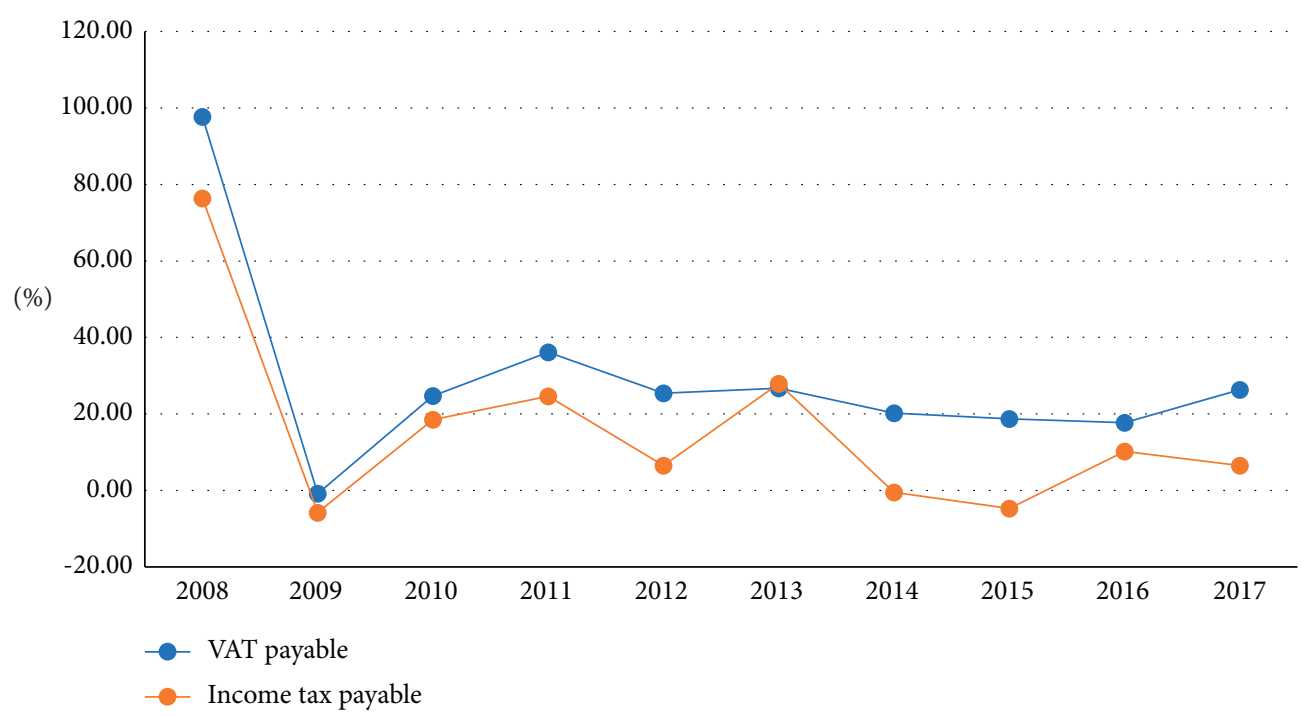

Figure 3: Tax trend chart.

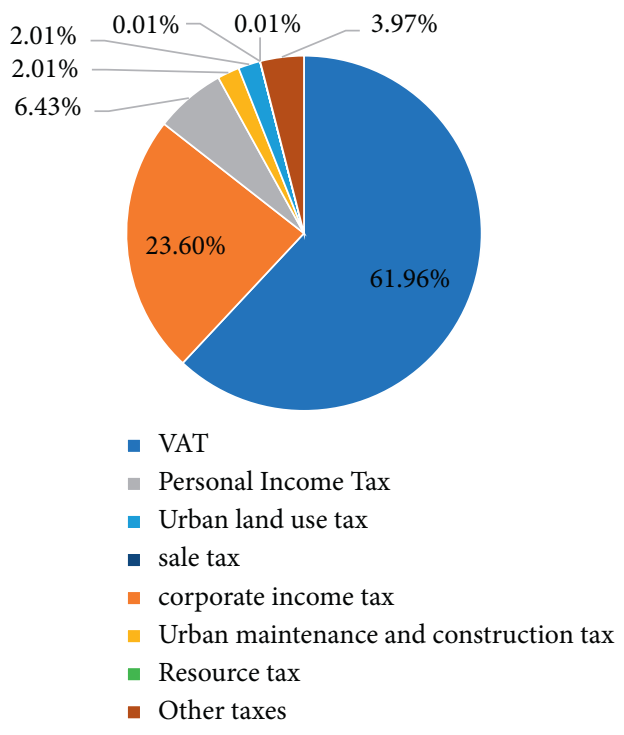

Figure 4: Tax ratio chart.

TABle 6: Main tax data.

\begin{tabular}{lccc}
\hline Index & 2015 & 2016 & 2017 \\
\hline Main business income & $19,318,312.97$ & $23,840,084.80$ & $24,013,964.88$ \\
Operating profit & $3,312,277.73$ & $3,902,178.45$ & $5,081,291.64$ \\
Total tax & $2,504,007.11$ & $3,376,031.20$ & $3,975,974.68$ \\
Corporate income tax & $894,889.84$ & $1,289,653.77$ & $1,648,790.07$ \\
VAT & $445,994.91$ & $968,907.43$ & $1,650,024.94$ \\
Land appreciation tax & $674,883.96$ & $1,023,643.55$ & $1,356,120.43$ \\
\hline
\end{tabular}

Table 7: Main tax index.

\begin{tabular}{|c|c|c|c|c|}
\hline Index & Calculation formula & 2015 & 2016 & 2017 \\
\hline Corporate income tax rate & Corporate income tax/operating profit & $27.02 \%$ & $33.05 \%$ & $32.45 \%$ \\
\hline Value-added tax rate & Value-added tax/main business income & $2.31 \%$ & $4.06 \%$ & $6.87 \%$ \\
\hline Land appreciation tax rate & Land value-added tax/main business income & $3.49 \%$ & $4.29 \%$ & $5.65 \%$ \\
\hline Comprehensive tax rate & Total tax payment/main business income & $12.96 \%$ & $14.16 \%$ & $16.56 \%$ \\
\hline
\end{tabular}


TABLE 8: Main taxation status of enterprises.

\begin{tabular}{|c|c|c|c|c|c|c|}
\hline Project & 2015 & Proportion & 2016 & Proportion & 2017 & Proportion \\
\hline Corporate income tax & $894,89.84$ & $28.51 \%$ & $1,9,53.77$ & $36.19 \%$ & $1,648,790.07$ & $32.28 \%$ \\
\hline VAT & $445,94.91$ & $14.21 \%$ & $968,907.43$ & $27.19 \%$ & $1,650,042.99$ & $31.30 \%$ \\
\hline Business tax & $674,83.96$ & $21.50 \%$ & $1,023,634.55$ & $28.72 \%$ & $1,356,120.43$ & $25.73 \%$ \\
\hline Business tax & $977,41.31$ & $31.16 \%$ & $99,166.01$ & $2.78 \%$ & $408,581.38$ & $7.75 \%$ \\
\hline City maintenance tax & $62,55.20$ & $1.99 \%$ & $81,278.50$ & $2.28 \%$ & $84,902.07$ & $1.61 \%$ \\
\hline Education surcharge & $42,718.09$ & $1.36 \%$ & $58,817.20$ & $1.65 \%$ & $61,758.72$ & $1.17 \%$ \\
\hline Other taxes & $39,944.12$ & $1.27 \%$ & $42,479.20$ & $1.19 \%$ & $60,860.47$ & $1.15 \%$ \\
\hline Total & $3,138,927.4$ & $100.00 \%$ & $3,563,936.66$ & $100.00 \%$ & $5,271,056.08$ & $100.00 \%$ \\
\hline
\end{tabular}

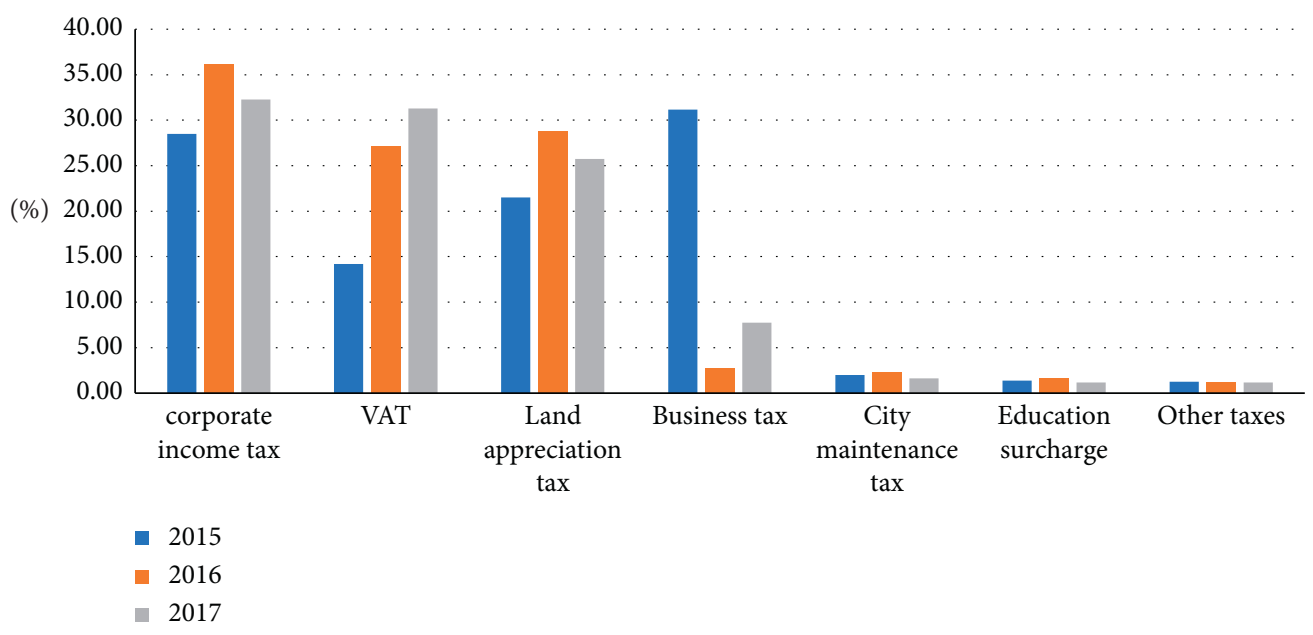

FIgURE 5: Taxation statistics chart.

TABle 9: Tax data for the pharmaceutical industry.

\begin{tabular}{cccccc}
\hline Years & $\begin{array}{c}\text { National tax } \\
\text { revenue }\end{array}$ & $\begin{array}{c}\text { Corporate tax } \\
\text { revenue }\end{array}$ & $\begin{array}{c}\text { Proportion of tax } \\
\text { revenue }\end{array}$ & $\begin{array}{c}\text { Corporate value-added } \\
\text { tax }\end{array}$ & $\begin{array}{c}\text { Value-added tax as a percentage of } \\
\text { tax }\end{array}$ \\
\hline 2015 & $110,530.7$ & 946.65 & $0.86 \%$ & 609.38 & $64.37 \%$ \\
2016 & $119,175.31$ & 1061.75 & $0.89 \%$ & 670.63 & $63.16 \%$ \\
2017 & $124,922.2$ & 1194.48 & $0.96 \%$ & 742.08 & $62.13 \%$ \\
2018 & $130,360.73$ & 1302.08 & $1.00 \%$ & 806.77 & $61.96 \%$ \\
\hline
\end{tabular}

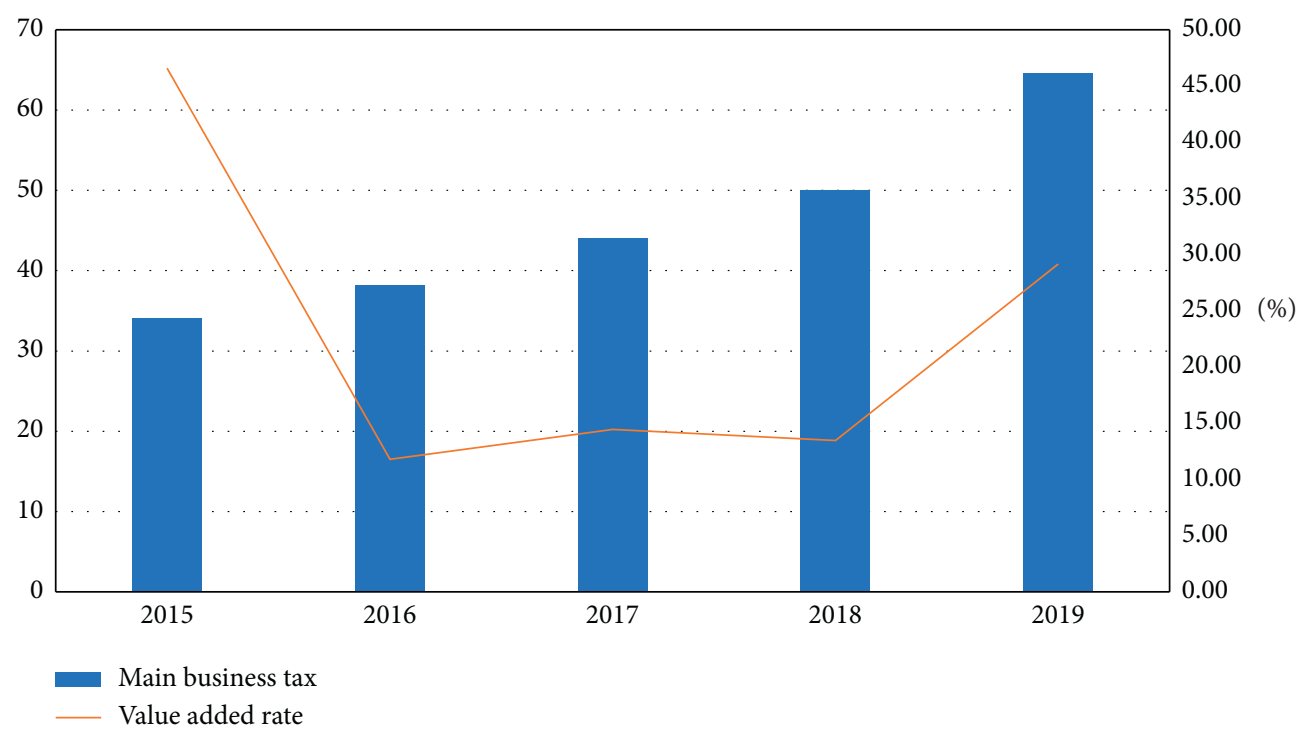

Figure 6: Tax data trend chart. 
TABle 10: Tax data sheet.

\begin{tabular}{lcc}
\hline Years & Main business taxes and surcharges & Value-added rate \\
\hline 2015 & 34.11 & $46.58 \%$ \\
2016 & 38.13 & $11.79 \%$ \\
2017 & 44.02 & $14.45 \%$ \\
2018 & 49.95 & $13.47 \%$ \\
2019 & 64.51 & $29.15 \%$ \\
\hline
\end{tabular}

We can see from Figure 6 and Table 10 that from 2013 to 2017, our country's tax funds also increased year by year, reaching a peak in 2017. Although the rate of appreciation was unstable, it remained above $10 \%$.

\section{Conclusion}

In the new era of socialist market economic system reform, stateowned enterprises have strengthened their understanding of tax management planning, followed the national tax law and tax policy, and established and improved the management system of state-owned enterprises in accordance with current market conditions and the actual operation and management of enterprises. They attach great importance to the training of highquality professional management talents, so that they can clarify the national tax law system, actively respond to the requirements of national laws and regulations, strengthen the risk awareness of tax management planning, ensure that the tax management planning of state-owned enterprises has certain flexibility, effectiveness, and operability, help to realize the efficient operation of state-owned enterprises funds, and ensure the maximization of management benefits. While improving the management level of state-owned enterprises and promoting the healthy development of enterprises, we should promote the construction and improvement of China's tax system, so as to lay a solid foundation for the construction of a socialist country under the rule of law.

\section{Data Availability}

The experimental data used to support the findings of this study are available from the corresponding author upon request.

\section{Conflicts of Interest}

The author declares that there are no conflicts of interest.

\section{Acknowledgments}

This study was sponsored in part by the Major Project of Fujian Social Science Research Base in 2020 (Research on Fiscal and Taxation Policies Supporting the Modernization of Fujian's Industrial Chain during the "14th Five-Year Plan"-Based on Four-Dimensional Docking) (FJ2020JDZ069).

\section{References}

[1] M. Zhang, "Research on the application of financial and taxation big data in enterprise taxation risk management," E3S Web of Conferences, vol. 218, Article ID 01053, 2020.
[2] P. Guo, "Linqu county build fiscal big data application platform and contribute to the construction of "smart finance"," Fiscal Science, vol. 2, no. 20, pp. 11-28, 2019.

[3] Y. J. Cui, "The application of artificial intelligence and big data in finance and taxation," Heilongjiang Science, vol. 10, no. 12, pp. 45-78, 2019.

[4] C. A. Gleason, M. Pincus, and S. O. Rego, "Consequences of material weaknesses in tax-related internal controls for financial reporting and earnings management," Ssrn Electronic Journal, vol. 12, no. 21, pp. 22-27, 2009.

[5] S. Zhu, J. Han, and Y. Hu, "Research on financial system safety performance under the basis of data," Mining Environment, vol. 8, no. 85, pp. 107-120, 2014.

[6] C. Peng, "Design and implementation of electronic network system of taxation based on the internet and big data perspective," in Proceedings of the Conference on Informatization in Education, pp. 52-85, Guangzhou, China, September 2015.

[7] A. Beatty and G. Harris, "Intra-group, interstate strategic income management for tax, financial reporting, and regulatory purposes," Accounting Review, vol. 12, no. 12, pp. 85-100, 2001.

[8] S. Yadav, "Discovering drivers of illicit financial flows-trade freedom," Taxes, and Transfer Pricing, vol. 10, no. 52, pp. 22-85, 2020.

[9] N. I. Karampinis and D. L. Hevas, "Effects of IFRS adoption on tax-induced incentives for financial earnings management: evidence from Greece," The International Journal of Accounting, vol. 48, no. 2, pp. 218-247, 2013.

[10] G. Enrique, V. Quadrini, and J. R1'os-Rull, "Financial integration, financial development, and global imbalances," Journal of Political Economy, vol. 117, no. 3, pp. 371-416, 2009.

[11] L. S. François, "Regulating cross-border data flows and privacy in the networked digital environment and global knowledge economy," International Data Privacy Law, vol. 2, pp. 93-104, 2012.

[12] K. Su-Keun and J. Park, "The effect of credit rating on determinants of audit fees -comparative analysis on listed firms and non-listed firms," Journal of Taxation and Accounting, vol. 11, no. 1, pp. 325-361, 2010.

[13] W. Qin and Q. Lin, "Construction of cultural industry development factor model based on factor analysis, artificial intelligence and big data," Microprocessors and Microsystems, vol. 82, no. 2, Article ID 103880, 2021.

[14] C. Y. Sun, Y. Zhao, and S. O. Finance, "Tax compliance risk identification and impact factor analysis under the"Big Data"algorithm," Modern Finance and Economics-Journal of Tianjin University of Finance and Economics, vol. 35, no. 6, pp. 1-7, 2015.

[15] L. Riccetti, A. Russo, and M. Gallegati, "Unemployment benefits and financial factors in an agent-based macroeconomic model," Economics Discussion Papers, vol. 9, no. 25, pp. 89-101, 2014.

[16] A. A. C. Azmi and K. A. Penumal, "2008Tax. fainess dimensions in an Asian context: the Malaysian perspective," International Review of Business Research Papers, vol. 4, no. 5, pp. 11-19, 2014.

[17] M. Gillman, "Income tax evasion: tax elasticity, welfare, and revenue," International Tax and Public Finance, vol. 28, no. 3, pp. 533-566, 2021.

[18] L. Balafoutas, A. Beck, R. Kerschbamer, and M. Sutter, "The hidden costs of tax evasion," Journal of Public Economics, vol. 129, pp. 14-25, 2015.

[19] S. Amponsah and K. O. Adu, "Factors influencing tax stamp purchases in Ghana: a case of twifo-AttiMorkwa sub-tax 
district," Journal of Neuroendocrinology, vol. 17, no. 11, pp. 720-726, 2016.

[20] G. Ştefura, "A new perspective on individual tax compliance: the role of the income source, audit probability and the chance of being detected," Usv Annals of Economics \& Public Administration, vol. 12, pp. 192-201, 2013.

[21] S. Eichfelder and C. Kegels, "Compliance costs caused by agency action? e," Journal of Economic Psychology, vol. 40, no. 40, pp. 200-219, 2014.

[22] A. Swistak, "Tax penalties in SME tax compliance," Financial Theory and Practice, vol. 40, pp. 130-149, 2016.

[23] L. P. Feld and B. S. Frey, "Tax compliance as the result of a psychological tax contract: the role of incentives and responsive regulation," Law \& Policy, vol. 29, no. 1, pp. 102-120, 2007.

[24] S. Dhami, "Why do people pay taxes? prospect theory versus expected utility theory," Journal of Economic Behavior \& Organization, vol. 64, no. 1, pp. 171-192, 2007.

[25] F. Frey and S. Bruno, "Deterrence and tax morale in the European union," European Review, vol. 11, no. 3, pp. 385-406, 2006. 